\title{
Preparing secondary teacher candidates to teach academic English
}

\author{
Stephanie Garrone-Shufran*
}

* Merrimack College, Winston School of Education and Social Policy, North Andover, MA, United States.

E-mail :

GarroneShufS@merrimack.edu

\section{Article Info}

Received: 23 July 2020

Revised: 15 January 2021

Accepted: 7 February 2021

\subsection{3/icsr.2021.1}

\section{How to cite}

Garrone-Shufran, S. (2021). Preparing secondary teacher candidates to teach academic English. Journal of Curriculum Studies Research, 3(2), 100-121.

https://doi.org/10.46303/jcsr.2021.1

\section{Copyright license}

This is an Open Access article distributed under the terms of the Creative Commons Attribution 4.0 International license.

https://creativecommons.org/licenses/by/4.0/

\section{ABSTRACT}

In this qualitative study, mainstream teacher candidates in a secondary teacher education program were asked to incorporate academic English instruction into their lesson planning and implementation in fieldwork placement classrooms. Teacher candidates attended a training session in which one method for identifying academic English features was taught. Artifacts, classroom observations, and interviews from four teacher candidates were analyzed to determine what features of academic English were identified and how these were taught to high school students. While all four teacher candidates accurately identified features of academic English in their lessons, only two participants taught features of academic English to students. The experiences of the participants illustrated that teacher candidates need, in addition to the ability to identify features of academic English, knowledge about how to teach language, a commitment to teaching language in their lessons, and the support of university supervisors and supervising practitioners who possess the same knowledge and commitment.

\section{KEYWORDS}

Academic language, high school, teacher education, English language learners. 


\section{INTRODUCTION}

Knowledge of Academic English ( $\mathrm{AE}$ ), the ways of using English that are valued in the various contexts of schooling, is necessary for students to be successful in American schools. Exposure to $A E$ outside of school seems to accelerate the process of learning this language, as students whose parents are fluent in AE tend to be more successful in school (Zacarian, 2013). Learners of $A E$, those students who have limited exposure to $A E$ outside of school, make up much of what Enright (2011) referred to as the "New Mainstream" in American schools. Success in school is more challenging for this population of students, because "their language experiences at home are not aligned with those at school" (Kalinowski et al., 2020, p. 2). Within this "New Mainstream" population are non-native English speakers, both those classified as English language learners (ELLs) and those who are fluent in English and their home language. Also included are students from lower socioeconomic backgrounds and those from diverse cultural and racial groups. To be inclusive of all students who make up the "New Mainstream", the term culturally and linguistically diverse (CLD) students will be used to describe them in this article.

The struggle to keep pace with peers who are fluent in AE grows more difficult as students enter the secondary grades (6-12), where AE becomes even more integral to success in school and also more challenging to learn (Kieffer, Lesaux, \& Snow, 2008; Schleppegrell, 2018). While the scores of all groups that include CLD students are not disaggregated in educational testing, the data gathered from ELLs may provide some indication of the impact that AE proficiency has on standardized test results. On the 2019 National Assessment of Educational Progress (NAEP) assessments, only $4 \%$ of ELLs in grade 8 scored at or above proficient in reading, while $36 \%$ of students not classified as ELLs scored at or above proficient (National Center for Educational Statistics, 2019). As Zacarian (2013) suggests, there is reason to "reframe the achievement gap as being between students who carry academic language and students who are learning academic language" (p. 21). In other words, for CLD students, the achievement gap may be more aptly referred to as the AE gap.

In recent years, policy has shifted from focusing on language development as separate from content area learning to integrating content and language learning into mainstream classrooms (Hakuta \& Pecheone, 2016). Educators are asking CLD students to learn both the content area concepts and the language used to express those concepts simultaneously (Schleppegrell, 2018). However, in order to develop proficiency in AE, students must be explicitly taught the language functions and features that they need to use to make meaning in the various academic disciplines (Lucas, Villegas, \& Freedson-Gonzalez, 2008).

Traditionally, mainstream teachers do not explicitly teach AE. This phenomenon is what Macedo (1994) called "a pedagogy of entrapment", in which schools "require from these linguistic-minority students precisely the academic discourse skills and knowledge bases they do not teach" (Bartolome \& Macedo, 1999, p. 228). Delpit (1995) explained that "the culture of power", which are the "codes and rules for participating in power" related to "linguistic forms, 
communicative strategies, and presentation of self," must be acquired to be successful in a society and suggested that teaching the codes and rules should be the responsibility of teachers who work with CLD students (p. 25). For CLD students to learn to use and understand AE, all teachers must undertake the dual tasks of both providing access to the content and designing experiences that will help students to develop the language valued in the discipline (Valdes, Bunch, Snow, \& Lee, 2005; Snow \& Uccelli, 2009).

Teachers can only offer explicit instruction in the AE of an academic discipline if they are trained to do so. Most teachers have a "fuzzy understanding" of what that language is (Lahey, 2017, p. 241). Teachers tend to come from middle-class, academically literate backgrounds and, for this reason, likely did not need explicit instruction in $A E$ to be successful in school (Morales \& Bardo, 2020). Their own schooling experiences, in which AE was not a barrier to learning, have made the language and literacy demands of content area classrooms "invisible" to them (deJong \& Harper, 2005). This is not to say that these content area teachers do not care about their CLD students but that they do not "allow that vision of care to extend to the political and social realities" of the students, which includes their differential access to the language valued in school (McCorkle, 2020, p. 34).

$A E$ is a complex construct that encompasses language functions and features that vary according to domain (listening, speaking, reading, or writing), grade level, content area, and context of use (Anstrom et al., 2010). For the purposes of this research, $A E$ is described in terms of the language functions it is used to accomplish and the linguistic features typically used in these functions. Language functions, the purposes for which language is used, common to $A E$ include explaining, summarizing, and arguing, and the use of certain linguistic features is necessary to express these functions appropriately (Dutro \& Moran, 2003). Students must use and understand precise academic terms, specific sentence structures, and organizational structures of various types as they read and write academic texts. Turkan et al. (2014) drew on Scarcella's (2003) framework of AE to classify the common features of AE at the word, sentence, and discourse level. The lexical component of $A E$ consists of the words students must know and what they must know about them. The grammatical component of AE includes constructions not commonly used in everyday contexts, such as conditionals and passive voice. Discourse level features are those that create organization and coherence, such as signal words used to illustrate the organization of a written text.

In order to prepare high school teachers to teach $A E$, secondary teacher education programs must begin to draw teacher candidates' (TCs') attention to teaching AE early in the required coursework and field experiences (Lahey, 2017). In this article, one training session designed to aid in the preparation of mainstream secondary TCs to identify and teach features of $A E$ in their content area lessons is described. The data presented were collected to determine how the TCs integrated what they learned about teaching AE into their lesson plans and how they implemented those lesson plans in their field experiences. 


\section{Research Questions}

1.) How do secondary TCs who have attended a training session on teaching Academic English incorporate instruction in that language into content area lessons in diverse fieldwork placement classrooms?

2.) What factors might impact the planning and teaching of Academic English in TCs' lessons?

\section{Literature Review}

Studies in which in-service and pre-service teachers have been trained to look at, rather than through, language (deJong \& Harper, 2005) and identify the features of AE that are present have found some evidence that participants can be taught to analyze the language of the classroom and discipline. Carter et al. (2016) designed a year-long professional learning opportunity in which 25 secondary teachers engaged in learning to identify and teach features of AE in their own content-specific materials and lessons. Exit surveys and classroom observations showed that teachers seemed to gain knowledge about the concept of $A E$, broadening their definitions to include both content-specific and general language features, and that participants planned more targeted instruction in academic vocabulary in their content area lessons (Carter et al, 2016). However, knowledge of AE goes beyond learning content-specific vocabulary (Jensen \& Thompson, 2020). Meier et al. (2020) found that the seven preservice secondary science teachers in their study developed a more nuanced understanding of academic language over the course of their program, moving from defining it solely as vocabulary to including higherlevel segments of scientific language. Instruction in academic language is necessary for preservice teachers to see both what this language is but also why it needs to be taught (He et al., 2018).

Approaches for training in-service and pre-service teachers must balance the delivery of knowledge about $A E$ with the development of practical strategies for applying that knowledge to teaching. In Willett and Correa's (2014) research, a course designed to teach in-service teachers about the concept of genre and the language features of each genre had to be revised after one iteration because the instructors found that teachers could identify some language features but "had difficulty addressing the particular language needs of their students" (p. 159). Similarly, in Schall-Leckrone and McQuillan's (2012) study of two cohorts of TCs who took slightly different iterations of a secondary history methods course, the researchers found that shifting the focus from analyzing $A E$ in texts to teaching strategies and applications to teaching seemed to create in TCs a stronger feeling of preparedness to work with CLD students.

While teachers may be able to identify features of $A E$, implementation of instruction in AE does not necessarily follow. Despite Carter et al.'s (2016) finding that teachers in professional development learned how to identify and teach some features of $A E$, the researchers acknowledged that only some of the participants chose to implement what they had learned in their classrooms. In Townsend's (2015) study of eight middle school teachers in a professional 
development program dedicated to identifying and teaching $A E$, participants' reflections and researchers' observations showed that teachers' implementation of strategies for language learning varied based on the content area taught, the teachers' commitment to spending time on language practice, and the teachers' background knowledge of the specific language features. TCs in Meier et al.'s (2020) study were able to explain multiple support strategies for building academic language proficiency, including engaging in hands-on activities, using comprehensible input, and modeling language use for students when interviewed; however, only some of these strategies were actually incorporated into the lesson plans written by these TCs.

An additional consideration for preparing teachers to teach $A E$ is program coherence. Schall-Leckrone and McQuillan (2012) found that secondary history TCs benefited from learning about effective instruction for CLD students from multiple sources at the same time, as several TCs in the second cohort, in which participants reported feeling more prepared to teach CLD students, were taking a course in teaching CLD students at the same time as they were taking the history methods course; this additional source of information about strategies for teaching CLD students may have influenced the students' feelings and, as a result, influenced their responses on the survey.

Support and mentoring from a more experienced educator has also been found to be important for preservice and in-service teachers who are learning to implement explicit instruction in AE. The TCs in Meier et al.'s (2020) study worked with supervising practitioners who had broader definitions of AE than simply vocabulary knowledge, reflecting what the TCS had learned in their courses. When Author (2014) trained five in-service high school teachers to identify features of $A E$ through engaging in analysis of content area texts, the three teachers who were interviewed found that the support of a language specialist was helpful as they were trying to plan language-focused lessons and reported that type of support had not been offered to them previously. Josh, the high school social studies teacher described in the study by He et al (2018), was offered support and opportunities for reflection by two teacher educators as he planned to teach language in his classroom. The presence of support and mentoring for teachers and TCs as they attempt to apply what they have learned about teaching AE seems to have an impact on both their ability and their willingness to implement instruction in AE.

\section{METHODOLOGY}

The research described was part of a larger mixed methods study to determine the effects of an intervention created to provide TCS with knowledge about identifying features of $A E$ and incorporating the teaching of those features into their content area lessons. In this article, the qualitative aspect of the study is described. Qualitative data sources were collected in order to provide in-depth descriptions of how individual TCs applied what they learned in the training as they planned and taught lessons in their fieldwork placements. A bounded case study design 
was employed to focus on the lesson planning and teaching of a small group of TCs who had received the training and who were completing fieldwork placements in a given semester.

\section{Participants}

Participants for this research were recruited during the mandatory training sessions held at the start of the semester. While a sample including TCs in all content areas was desirable, the sample chosen represented the high numbers of students pursuing history and English teaching degrees at the institution. The four participants discussed were part of a larger sample of eight TCs who consented to participate. See Table 1.

Table 1

Demographic Information for TCS

\begin{tabular}{llllll}
\hline & & & Fieldwork & Content & Placement Site \\
Name & Gender & L1 & Experiences & Area & \\
\hline Jill & F & English & 2 & History & High School A \\
Carly & $F$ & English & 2 & English & High School B \\
Lucas & $M$ & English & 3 & History & High School A \\
Felix & $M$ & English & 3 & History & High School B \\
\hline
\end{tabular}

Jill, Carly, Lucas, and Felix were chosen for this article because they completed field experiences at diverse suburban high schools with similarly large populations of CLD students who might benefit from explicit instruction in AE. Jill and Lucas were placed at High School A, located in a town that had seen a recent influx of immigrants from Central America. Latinx students comprised $34 \%$ of the student body at the high school. The high school population included 39.4\% First Language Not English (FLNE) students with $11.7 \%$ of the student body classified as English Language Learner (ELL) students. Felix and Carly were placed at High School $B$, located in a city with a large Asian population. Asian students accounted for $54.3 \%$ of the population of this high school. Students classified as FLNE accounted for $47.2 \%$ of the student body and $12.3 \%$ of students were classified as ELL.

\section{Data Sources}

Data sources for this research included a completed lesson planning worksheet (Appendix), a written lesson plan, an observed lesson, and an interview. The lesson planning worksheet was designed to be a scaffold for TCS to identify the functions and features of AE that they would need to teach to students. A TC would be expected to complete this lesson planning worksheet alongside their actual lesson plan for the placement classroom. The corresponding lesson plan was also collected. Lesson plans were submitted in the format used by the teacher education program; all of the lesson plans contained the same elements in the same order: standards, 
content and language objectives, a description of the lesson's assessment, and the procedure (the step-by-step explanation of how the lesson would be taught).

Lessons would be observed in person by the researcher whenever possible. The audio of each lesson was recorded. The researcher would also take notes as the lesson was taught. The interviews with the TCs were audiorecorded as well. In the first part of the interview, TCs were asked to engage in a think-aloud. The think-aloud was utilized as a way to illustrate how TCs verbalized the process of identifying the $A E$ present in their content area lessons and how they might apply their knowledge as they plan. In the second part of the interview, the TCs were asked questions about the lesson they taught; they were asked for clarification or explanation of any instances in which they discussed features of $A E$ with students. In the third section of the interview, TCs reflected on what they learned from the training session.

\section{Data Collection}

The research was conducted in the undergraduate secondary teacher education program at a private university located in a suburb of a large city in the northeastern United States. In this program, TCs must complete three required pre-practicum experiences before their full practicum experience. In these pre-practicum experiences, they are assigned to work with one or more supervising practitioners at a school site. Each TC also has a university supervisor, often a graduate student from the education program, who is responsible for observing and supporting the TC during the experience. TCs are required to plan and teach a certain number of lessons in each of the three pre-practicum placements: two lessons in their first placement, three lessons in their second, and four lessons in their third.

The intervention studied in this research was the mandatory training session for all secondary TCs who were planning to complete a pre-practicum experience. All TCs in the secondary (grades 8-12) education program completing a pre-practicum placement were required to attend a two-hour training session about teaching $A E$ in the content areas. In these interactive workshops, TCs were taught a process for identifying the features of AE present in their content area lessons and planning instruction of those features in their lessons.

TCs were instructed to bring a lesson plan which they had previously planned and taught with them to the training session. In the training session, the process of using the lesson planning worksheet was modeled. After the teacher educator modeled each step of the process using a sample lesson, the TCs practiced that step using the lesson plan they had brought. The workshops were conducted with small groups of students so that students received individualized attention from the instructor as they identified $A E$ features in their lesson plans.

As a first step toward identifying the linguistic features present in content area tasks, TCs were asked to classify each instance in which students were asked to use or understand $A E$ in their lesson plans as a listening, speaking, reading, and/or writing demand. After determining the two most important language demands in the lesson, they named the language functions (such as explain, describe, define, and compare) that best described the tasks. TCs then decided 
what language features at the word, sentence, and discourse-level needed to be used in completing those tasks. Word-level features were categorized into two types: general academic words used across content areas and technical words used in a specific discipline. To describe sentence-level structures, students engaged in a brainstorm to think about what are some of the features that are important to writing a correct sentence. Typical responses included verb forms or tenses, nouns, article use, commas, and periods. Discourse-level structures were defined as the amount and quality of language as well as coherence. The example provided for TCs was the typical paragraph structure taught to students: a topic sentence, three sentences that support the topic, and a concluding sentence. There is a specified amount of language (five sentences) and an expected organization (topic sentence, three details and a conclusion). Finally, to reinforce the idea that TCs were responsible for teaching these language features to students, TCs were shown both how to create specific language objectives naming these required features and how to explicitly describe how they would teach the features of $A E$ they identified in the lesson procedure section of their lesson plan.

The TCs consented to be observed teaching one lesson in their placement classrooms. They were asked to submit via email the lesson plan and lesson planning worksheet for this lesson the night before they taught it. Three of the four lessons taught were observed in person; Lucas's lesson was taught at the same time as another participant's lesson so Lucas recorded his own lesson using a provided digital recorder. Recordings of the lessons were transcribed before each TC was interviewed. Each TC sat for an interview as soon after he/she taught the observed lesson as possible; The length of time between the teaching of the observed lesson and the interview varied from 24 hours to four days. Interviews were digitally recorded and then transcribed.

\section{Data Analysis}

The purpose for collecting the lesson planning worksheet and lesson plan was to determine what TCs identified in terms of features of $A E$ and to what extent they incorporated those features of $A E$ into their lesson plans. These written documents were analyzed using a researcher-created recording sheet. On these sheets, there were spaces to record exactly what TCs wrote on these documents as well as charts in which the number of identifications they made could be recorded. Using the recording sheet also provided a way to determine the extent to which TCs incorporated features of AE into their lesson plan. TCs had been instructed in the training session to name specific features of $A E$ in the language objective(s) and then describe how they would teach those features to students in the lesson procedure section of the lesson plan. If a TC had named specific features of $A E$ in a lesson plan, it was noted on the recording sheet if the TC included the features of $A E$ in the language objective(s), in the lesson procedure section, or both.

Since TCs were asked to supply their own identifications, their responses on the lesson planning worksheet and lesson plan varied greatly in wording and specificity, leaving room for 
judgment in terms of categorizing these identifications. A second rater, a doctoral student with a background in linguistics and some familiarity with the concept of AE from her experience both as a research assistant and as a grader for the teaching CLD students course, was engaged in the analysis. The criteria used to categorize identifications was reviewed and that criteria was used to evaluate the identifications on one document together. Once agreement had been reached on the responses on that document, both raters would then fill out the recording sheet, evaluating a set number of documents independently and stopping to compare categorizations. Discrepancies in categorization were discussed, and, for each discrepancy, each explained their reasons for placing the identification in that category. Previous decisions regarding categorization were discussed to help in coming to consensus on a category.

A constructivist grounded theory approach was used to code the transcripts of the observed lessons and interviews of the TCs (Charmaz, 2000). The goal in analyzing these data sources was to discover how the TCs described their approaches to the process of identifying and teaching $A E$ in actual lessons that they created and taught. Grounded theory was used to conduct the analysis of the lessons and interviews because, according to Charmaz (2006), the use of grounded theory "reduce[s] the likelihood that researchers merely superimpose their preconceived notions on the data" (p. 51). Transcripts of the lessons and the interviews were coded using qualitative data analysis software.

Coding began with a line by line process for the interview transcripts. Whenever possible in vivo codes were utilized. These codes included "naming functions and features is harder", "never gotten feedback from supervisor about language", "thinking about the words I'm saying", and "seeing academic language is an additive-type thing". With all of the documents coded, codes within each case were examined and compared first in order to get a sense of the TCs' full experience of planning and teaching and how he/she chose to describe this experience. Then the focused coding phase (Charmaz, 2006) was begun: a complete list of action codes from the lesson and the interviews was compiled, along with the excerpts to which they were assigned. From these action codes, ideas about the processes in which TCs engaged as they planned and taught lessons as well as the factors that influenced those processes began to take shape. The different aspects of the process and the influential factors TCs discussed became the selective codes. These selective codes included "writing language objectives", "incorporating supervisor feedback on academic language", and "defining vocabulary words".

At this point in the process, memo writing (Charmaz, 2000) was utilized. When a theme was perceived to be emerging in the data, a memo exploring what had been found and how it related to the questions about TCs' planning and teaching of lessons was written. In writing these memos, explanations of the themes became clearer. After exploring the data and writing in this way, the selective codes were then grouped into three big categories: "planning", "teaching", and "assessing student learning". These categories helped to explain the process that TCs were enacting as they planned and taught their lessons and allowed for the inclusion of TCs' reflections on the process and on students' learning of $A E$ in their lessons. As the analysis 
continued, the codes and memos were considered as aspects of the answers to the research questions regarding the presence of $A E$ in the planning and teaching of these lessons and the influence that the training and any other factors may have had on TCs' planning and teaching processes.

In terms of triangulation, Creswell (2008) wrote that reinforcement of observations may be built through "corroborating evidence from different individuals (e.g. a principal and student), types of data (e.g. observational fieldnotes and interviews), or methods of data collection" (p. 266). In this research design, triangulation was employed in the categorization of the identifications that TCs made on lesson plans and lesson planning worksheets. Employing a second rater offered another perspective on how the identifications should be categorized, which helped to guard against the subjectivity that comes with having designed and delivered the trainings. The research design provided opportunities to collect data from different sources using different methods. The qualitative data included observational data in the form of the lesson as well as an interview with the participants. The data from these two sources were combined for the purpose of explaining TCs' planning and teaching process. Two written data sources, the worksheet and the lesson plan, were included in order to create a complete description of the TCs' planning and teaching of the lesson

\section{RESULTS AND DISCUSSION}

In reference to the first research question, while all four TCs identified specific features of $A E$ that they could teach to students on their lesson planning worksheets, not all of the TCs taught features of $A E$ in their observed lessons. Jill and Lucas did not teach any features of $A E$, while Felix and Carly each taught at least one feature.

\section{No Teaching of AE in the Lesson}

Jill. Jill, an aspiring history teacher, was completing her second pre-practicum experience. She planned for students to work in small groups to read and answer questions about a World War I poem and then share their answers with the whole class. All groups were expected to name the tone of the poem, whether it was pro-war or anti-war, what point of view the poem was told from. On her lesson planning worksheet, Jill had identified several specific features of $A E$ students would need to use or understand: the terms tone, pro/anti-war, point of view, reliability, and validity and the sentence starters "This poem is pro/anti-war because", "The tone of this poem is", and "This poem is written from the point of view". Jill did not include any of these features of $A E$ in her written lesson plan.

When she taught the lesson, Jill read one poem with the students and asked them the types of questions that they would later answer in their groups. While presenting the assignment to students, Jill used the terms tone, pro/anti-war, and point of view but she did not define or explain these terms for students. Despite the fact that she had identified specific 
sentence starters for students to use when she completed the lesson planning worksheet, she told students when they asked that they did not need to answer the questions in complete sentences. She thought that requiring complete sentences would not have necessarily made any difference, because she didn't think "it would have changed the message of what they were writing down."

When asked in the interview about students' ability to complete the assignment she designed, she said that students had difficulty determining "whether or not you could really use the poem as a valid source." She cited an example of one student who "didn't understand that because [the poet] was a doctor and he was well known in the society that, therefore, he would really be respected and people would believe him more." When asked if she thought the student did not understand what she meant by valid, she replied, "What he most struggled with was reliability, because he was missing the fact that the poet was a doctor and he was well respected." She was focused only on the application of the terms validity and reliability to the questions students needed to answer. She did not connect students' struggles to answer these questions to larger issues of AE proficiency, including knowledge of the terms valid and reliable as she was using them in this lesson.

Lucas. Lucas was completing his third and final pre-practicum experience at the same diverse, suburban high school where Jill was teaching. Lucas's eleventh-grade history lesson featured two activities. First, in the simulation activity, which his supervising practitioner designed, students were grouped into "Depression families" of different sizes, given a budget of $\$ 7$ to buy food for their family, and instructed to make a grocery list and fill in a menu chart. On the lesson planning worksheet, Lucas had indicated that students should complete the list in an "organized fashion", but he did not name any particular way in which students should organize the lists. He explained, "Any way they organized it would have been fine so long as it was organized in some fashion." In his lesson plan, he reiterated this non-specific organizational requirement in the language objective, which stated that students will "create a shopping list for groceries they'll need to feed a family for a week in an appropriate style with items listed in an organized fashion."

Delivering the instructions for this activity was really the only instance in the teaching of this lesson when Lucas addressed the whole class, and he did not tell students that they should organize the list. When asked why he did not bring up the idea of organization, Lucas admitted that the activity had not been designed by him.

One of the problems with this lesson was that I was using a pre-made worksheet my CT had given to me. Had I been making the worksheet myself, these instructions would have been included right in there. I would have stated out in writing, "Be sure to organize things in some way. You can decide how you want to as long as it's done."

The other language-based task described in Lucas's lesson plan is an exit ticket in which students would express their feelings about the simulation in which they had participated. This 
assessment was the only aspect of the lesson that Lucas created himself. On the lesson planning worksheet, Lucas named several specific features of $A E$ that students should use in their exit ticket responses: "transitions words like 'because', sentence starters such as 'I feel' or 'I think' or 'I'm of the opinion that', a strong opening sentence that explains what the paragraph will be about, and a strong closing that makes the reader reflect." While his language objective did not include any of these specific features, just below the language objective, in the section that asks TCs to describe how they plan to assess students' attainment of the objective, Lucas wrote, "Students will write a five-sentence paragraph exit ticket expressing how they felt with a main idea at the beginning of the paragraph, an explanation/defense of their feelings, and a strong closing that makes the reader think or reflect." In his interview, Lucas demonstrated how he would have told students about the features of $A E$ they needed to use when completing their exit ticket.

Everyone take out a piece of paper. I would like you to write a 5 sentence paragraph on how you felt during this activity, how it might have changed your views. I want it to start off strong, really set up your argument. Defend it throughout. And in the closing don't just restate what's already been stated. Say something new and try to make it leave me thinking.

He was demonstrating how he would have introduced the assignment, because students were not asked to complete this assignment during the lesson. Lucas explained, "My CT didn't tell me but he was handing out books, so he handed them out and they had to write down the page numbers and that took 15 minutes. Unfortunately with that, there wasn't time." Lucas had tried to plan the lesson so that he would have time at the end for the exit ticket, but his supervising practitioner's decision to hand out books interfered with his plan.

Lucas realized that changes should be made to the lesson to ensure that students would be aware of the features of $A E$ they were expected to use. He listed the revisions that he would make if he taught the lesson again.

I probably would retype the activity myself as I said with the listing. I would have the AE goals clearly stated to try to get more organized lists. I would try to shorten the activity a bit to make sure I had time to get to the activity, the exit ticket, in the end. I also would type up the directions for the exit ticket on a piece of paper and hand those out to students as opposed to going over it, as opposed to just saying it.

\section{Teaching of $A E$ in the Lesson}

Felix. Felix's tenth-grade history lesson on the Congress of Vienna consisted of a lecture with multiple "turn and talk" opportunities, a vocabulary activity, and an exit ticket. Felix added the vocabulary activity, which was designed to deepen students' understanding of the word alliance, to his lesson after he realized that the lesson planning worksheet asked for TCs to identify features of $A E$ for two important uses of language in the lesson plan. The vocabulary 
activity required students to "brainstorm with a partner, and come up with 2 synonyms, 2 antonyms, and 2 famous examples of alliances". Felix was not sure where he got the idea for this vocabulary teaching strategy he used in his lesson, but he said that generating synonyms and antonyms seemed like a good exercise for this word.

At the end of class, students were assigned an exit ticket, which asked them to compare Europe before and after the Congress of Vienna. On the lesson planning worksheet, Felix listed several specific features of $A E$ that students should use in their comparison, the words "before, after, whereas, both", the sentence level structure "Before the Congress of Vienna whereas after the Congress of Vienna ", and the discourse-level requirement of a fivesentence response. He did not mention these specific features either in his lesson plan or during his teaching of this lesson. In the lesson plan, there is a language objective that corresponds to the completion of this exit ticket but it states that students will complete the exit ticket "using compare and contrasting words".

In his lesson plan, the directions for the exit ticket stated that students needed to answer "[i]n a short paragraph (3-5 sentences)." When Felix asked the students to complete the exit ticket at the end of class, he informed students of this requirement. In assessing the exit tickets, Felix found that all students wrote at least three sentences, and "[m]ost of them actually went five which is great." He did not find that students used any comparing and contrasting words, the feature of language he had included in his language objective.

I guess in the exit tickets that they don't really reflect that like, "before the Congress of Vienna". It was just like "The congress of Vienna did this" or "This happened" so I guess it wasn't really a true comparison.

He was aware that he had not actually modeled the language he had included in the language objective. Felix felt that both modeling the sentence structure and providing a written reminder on the exit ticket assignment would encourage more students to use the language of comparison and, therefore, help them to create stronger comparison sentences.

Despite the fact that Felix explained how he had used the lesson planning worksheet to help him create language-based activities and identify features of $A E$ that he would teach, he still felt that there was a disconnect between being able to identify features of $A E$ and actually teaching those features to students. When asked if there was anything that the teacher education program could do to help him bridge the gap between identifying and teaching $A E$, he seemed convinced that the responsibility was his. "You guys have shown how important it is. But I guess it's just on me to focus more explicitly on it and incorporate it."

Carly. Carly, in her second pre-practicum experience, had the same placement site and the same supervisor as Felix. Her tenth-grade English lesson incorporated two activities in which students needed to understand or use Shakespearean language. In the first activity, students needed to "retell an excerpt from Romeo and Juliet in their own words," which is how the task is described in the first language objective in her lesson plan. Carly wrote in her lesson plan that she would "project on the board definitions of the 'tricky' words in the dialogue" to help 
students as they rewrote the scene in their own words. As she had written in the lesson procedure, during the lesson she showed students a Power Point slide with the "tricky" words, which were wherefore, art, thou, thy, wilt, 'tis, and thyself, and their modern-day equivalents; she read these pairs of words aloud to students.

The second language objective written in the lesson plan described the other activity planned for this lesson, in which students "compose their own dialogue using Shakespearean language in pairs by writing a conversation with five lines of dialogue using six of the common Shakespeare words, two pronouns, two adverbs or nouns or verbs, and two greetings." Carly planned to both explain the instructions and use an example she created to model the process of creating the dialogues for her students. She projected two versions of a three-line dialogue that she had written, one in modern language and one using Shakespearean words and phrases. She used a think-aloud procedure to explain to students how she translated her original dialogue by substituting the modern words and phrases for words and phrases from the list.

So I used one of the greetings that's on the sheet that says how fares and then the person's name. That means "how are you", so I just changed it to "How fares my friend?" And then I looked at the response. Good can stay the same. And then on the sheet and it says for slowly he uses but soft. So it says "How soft doth school seem". Doth means does, so I kind of had to change the way that I said the second line. It's still basically what I said just using his words.

Carly explained in her interview that she felt that it was the appropriate scaffold to use to assist the students in this class completing the task.

It actually is a strategy that I learned in that class - the teaching bilingual students one. . I think sometimes it's beneficial for all students, but especially students that are ELL or special needs, to see how it's modeled or how the thinking process that goes behind it.

Carly felt that students were fairly successful in using the required features of AE. All the dialogues all had five lines, and all of the pairs had used the two greetings and two pronouns, as they were instructed. However, she had noticed that they struggled to use the "other words" from the first section correctly. "Most of them had those types of elements, but as I was reading through them some of them didn't make sense." Carly explained why she thought they might have struggled with this task.

[T] hey didn't understand that they would have to change the structure of the sentence that they wrote in English to fit the word in Shakespearean language, which I tried to model in my think-aloud. One of the phrases I had I changed to fit the word. But if they didn't understand how you would change it, they just put the word into the sentence.

She had originally wanted to spend some time during the lesson going over the parts of speech and how they are used in sentences so that students would understand not just that they needed to use these different types of words in their dialogues but how to use the words 
correctly. However, she explained, "I couldn't, when I was planning the lesson, find a good time to incorporate it into that with the content my CT wanted me to cover."

\section{Implementing Instruction in AE}

As Carter et al. (2016) and Townsend (2015) found, the ability to identify features of AE does not necessarily lead to teaching AE. Based on the descriptions of the planning and teaching processes of these four TCs, it became clear that the training session had some impact on TCs' ability to identify features of AE but did not necessarily lead to the TCs actually teaching features of $A E$ in their content area lesson.

\section{Factors that Impact the Teaching of AE}

To answer the second research question, it was necessary to examine the TCs' reflections on their lesson planning and implementation. For Felix and Carly, having taken the course on teaching CLD students seemed to impact their implementation of language instruction. Carly had taken the required course on teaching CLD students in the spring semester of the previous school year, when the researcher was the course instructor. Felix was enrolled in the same semester in which this research was conducted; the instructor of the course was also his prepracticum supervisor. In their observed lessons, both TCs implemented strategies that are taught in this course: the think-aloud procedure utilized by Carly and the vocabulary activity implemented by Felix. Although only Carly reported that she had learned about the strategy she used in the course, it is likely that Felix learned the strategy he used in the course as well, since the exercise he implemented is an exact match for the way in which the four-square vocabulary template is taught. As the studies by Willett and Correa (2014) and Schall-Leckrone and McQuillan (2012) found, knowledge of practical strategies for teaching language may make TCs more likely to actually implement instruction in AE.

The course also seemed to provide TCs with an understanding that all CLD students, whether they are classified as EL or not, require instruction in AE. TCS who had taken the course based their decisions to teach AE on the presence of CLD students, not just EL students, in their placement classrooms. Carly had noticed that there were students with diverse linguistic backgrounds at the school, as she remarked in her interview, "I've noticed there's a high Asian population at that school. I've noticed some kids even in honors and AP classes that struggle with speaking English." Although Carly had asked her supervising practitioner who the ELL students in the class were, as she thought there might be a few, her supervising practitioner had not provided her with that information. When her supervising practitioner did not provide her with the requested information, Carly went ahead with teaching features of $A E$ anyway. Similarly, even though Felix did not feel that he had seen students struggling with language in the class in which he taught, he knew that "there are some students that speak a different language at home." Despite his belief that there were no ELLs in his class, he incorporated instruction in features of AE. As Carly did, he based his instructional decisions on his perceptions of who his students were. Both Carly and Felix seemed to recognize that they were teaching in 
"New Mainstream" (Enright, 2011) classrooms in which students from different linguistic backgrounds with varied exposure to AE rely on instruction in both content and language to access the curriculum.

The TCs who did not teach features of AE expressed little recognition of student diversity beyond the identification of ELLs. Despite the diversity of the overall school population, Jill's supervising practitioner had told her there were no ELL students in the class in which she taught this lesson. She said in her interview:

I think if I was working specifically with ELL students then I probably would have said, yes, use complete sentences to really enforce the language objective. But because the students weren't ELL students, I didn't really think about trying to also enforce this language objective upon them.

It seemed that Jill believed only ELLs would require language instruction. Lucas reported that his class had "really no ELLs". However, considering the diversity of the student population at their placement school, there were likely CLD students in both his and Jill's classes who would have benefitted from instruction in AE in their history classes.

The need for support and coaching from mentors in planning and implementing instruction in AE discussed by Author (2014), He et al. (2018), and Meier et al. (2020) was illustrated by the findings of this study as well. The TCs who taught features of AE worked with a mentor who was able to support them in identifying and teaching language features. Felix and Carly's supervisor was one of the instructors of the required course on teaching CLD students. As she guided the TCs in their lesson planning process, she offered support and advice on how to integrate the teaching of language into their lessons. Both TCs described receiving feedback from her about their language objectives, in which she reminded them to include specific features of $A E$ in their objectives. On the lesson planning worksheet, Carly named as a wordlevel feature, "at least six words that were common in Shakespeare's time". However, Carly's supervisor told her that this description of the vocabulary could be more specific. Carly recalled that she "changed it from originally just have them use 6 words to having them use 2 of the different types of words [pronouns; adverbs, nouns, or verbs; and greetings] which was her suggestion."

This supervisor also told Felix that, in his language objectives, he needed to "specifically refer to the language that students are expected to use and that you have to teach to them." He added the phrase "using comparing and contrasting words" based on his supervisor's comment that his original language objective was not specific enough. In the end, he was not sure that this change had matched what she wanted him to do. "So did I make the change? I guess I really didn't make too much of change but I added using compare and contrast words. . . I guess I'm still a little up in the air, confused". While Felix's revision may not have been successful in that he neither taught nor required the use of the features he stated in the objective, the feedback his supervisor provided did make him focus on language and language use in his lesson. 
Jill and Lucas had different supervising practitioners but the same supervisor. In planning the lesson, Jill reported receiving no help from her supervising practitioner or supervisor. When Lucas was asked if he received any help from anyone in planning his lessons, he replied, "I didn't really get any comments at all". However, Lucas later explained that the lesson activity, a simulation designed to teach students about how the Great Depression affected poor families, had been entirely created by his supervising practitioner. He had added the exit ticket, which students were not asked to complete during the implementation of the lesson due to his supervising practitioner's decision to distribute books instead. Lucas's supervising practitioner not only planned the lesson but also chose to alter the lesson plan as it was being enacted.

The experiences of these four TCs illustrate what Feiman Nemser and Buchmann (1985) described in their work on the "pitfalls of experience". The "two worlds" pitfall acknowledges that teacher education goes on in two distinct settings, the university and the field, and that TCs need assistance to understand how the knowledge that they are learning through coursework should be applied to the actual practice of teaching. Unlike what Felix said in his interview, it is not "just on [TCs] to focus more explicitly on it and incorporate it". TCs need the support of supervisors who can assist them as they apply their knowledge about teaching AE to their own discipline-specific practice. In this research, Felix and Carly, the TCs who received feedback related to language teaching from a supervisor, did teach language in their lessons. Jill and Lucas, who did not receive this type of feedback, did not integrate any language teaching into their lessons.

Additionally, Lucas replicated the exact practices of his supervising practitioner, illustrating the "cross purposes" pitfall. In classrooms, the goal of helping TCs learn to teach is often subordinated to the desire of supervising practitioners to maintain the routines and practices that they have established for their students (Feiman Nemser \& Buchmann, 1985). Lucas was instructed to enact his supervising practitioner's teaching practices uncritically, a danger of fieldwork experiences highlighted by Sleeter (2008) who warned that teacher education programs must be careful to prepare teachers "who do not simply replicate prevailing practices" (p. 568). In Lucas's experience, a vicious cycle in teacher preparation was repeated, a cycle in which TCs continue to enact the teaching practices currently accepted in school, most of which offer CLD students no opportunities to learn $A E$ and improve their educational outcomes.

Felix and Carly, in addition to receiving the training described in this study, also previously learned about teaching CLD students and received support in incorporating AE into their lesson plans from their pre-practicum supervisor. Jill and Lucas had neither the prior knowledge nor the support of a mentor to guide them in the teaching of $A E$. The findings of this study suggest that program coherence - providing TCs with the knowledge and the support required for implementing language instruction in the training, their university coursework, and their collaboration with supervisors and supervising practitioners - was more influential on the TCs' implementation of instruction in AE than any one factor on its own. 
Darling-Hammond (2006) wrote, "[i]t is impossible to teach people how to teach powerfully by asking them to imagine what they have never seen or to suggest they 'do the opposite' of what they have observed in the classroom" (p. 308). While the support of a supervisor who was able to assist TCs as they were learning to identify and teach features of AE seemed to make a difference, the TCs in this study did not observe in-service high school teachers implementing lessons that incorporated the teaching of $A E$. The ideal situation for preparing TCs to incorporate language instruction into their content area lessons would include both university supervisors who can help TCs identify features of AE and supervising practitioners who can model lessons in which content and language are taught simultaneously. For this reason, it would be beneficial for teacher education programs to provide their university supervisors and supervising practitioners with professional development opportunities that would allow them to assist the TCs with whom they work in adopting effective teaching practices that support the academic achievement of all students. Additionally, offering this type of professional development and coaching to supervising practitioners may help them to plan and implement effective instruction in features of $A E$, instruction that would benefit the CLD students in their classes.

\section{CONCLUSION}

More research on the development of language knowledge involving larger groups of TCs with more diversity in terms of content area, as well as longitudinal studies focused on individual TC's development of language knowledge during their time in teacher education programs, is necessary. There is also a need for research on what the university supervisors and supervising practitioners who work with TCs in their high school fieldwork placements know about teaching $A E$ and how initiatives designed to provide them knowledge about teaching AE might impact their work with TCs.

TCs must be supported in their efforts to integrate the teaching of AE into their lessons by university supervisors and supervising practitioners who themselves have both knowledge about teaching $A E$ and the understanding of the responsibility of all teachers to provide instruction in AE. Offering professional development initiatives designed to build this knowledge would both better prepare them to serve as mentors for TCs who are learning to integrate the teaching of $A E$ into the content area lessons and help them begin to integrate the teaching of $A E$ into their own classrooms, which would provide CLD students in these mainstream classrooms with the language instruction they need to be successful in school. It is the responsibility of teacher education programs to prepare the teachers of tomorrow for the students who will populate their classrooms. However, the CLD students of today can not wait for those new teachers to take over. By offering opportunities for in-service teachers to develop the knowledge about language necessary to teach $A E$ in their mainstream classes, teacher education programs can ensure that the change begins now. 


\section{REFERENCES}

Anstrom, K., DiCerbo, P., Butler, F., Katz, A., Millett, J., \& Rivera, C. (2010). A review of the literature on Academic English: Implications for K-12 English language learners. Arlington, VA: The George Washington University Center for Equity and Excellence in Education.

Bartolome, L.I., \& Macedo, D. (1999). (Mis)educating Mexican Americans through language. In T. Heubner \& K.A. Davis (Eds.). Sociopolitical perspectives on language policy and language planning. New York, NY: John Benjamins.

Carter, H., Crowley, K., Townsend, D.R., \& Barone, D. (2016). Secondary teachers' reflections from a year of professional learning related to academic language. Journal of Adolescent and Adult Literacy 60 (3), 325-334.

Charmaz, K. (2000). Grounded theory: Objectivist and constructivist methods. In N.K. Denzin, \& Y. S. Lincoln (Eds.), Handbook of qualitative research (pp. 509-535). Thousand Oaks, CA: Sage.

Charmaz, K. (2006). Constructing grounded theory: A practical guide through qualitative analysis. London, England: Sage.

Creswell, J.W. (2008). Educational research: Planning, conducting, and evaluating quantitative and qualitative research. Upper Saddle River, NJ: Pearson.

Darling-Hammond, L. (2006). Constructing $21^{\text {st }}$ century teacher education. Journal of Teacher Education, 57(3), 300-314.

Delpit, L. (1995). Other people's children: Cultural conflict in the classroom. New York, NY: New Press.

deJong, E.J., and Harper, C.A. (2005). Preparing mainstream teachers for English-language learners: Is being a good teacher good enough? Teacher Education Quarterly, 32 (2), 101124.

Dutro, S., and Moran, C. (2003). Rethinking English language instruction: An architectural approach. In G. García (Ed.), English language learners: Reaching the highest level of English literacy. Newark, DE: International Reading Association.

Enright, K. A. (2011). Language and literacy for a new mainstream. American Educational Research Journal, 48(1), 80-118.

Feiman-Nemser, S., \& Buchmann, M. (1985). The pitfalls of experience in teacher education. Teachers College Record, 87(1), 53-65.

Hakuta, K., \& Pecheone, R. (2016). Memo: Supporting English learners and treating bilingualism as an asset. In M. Hansen \& J. Valant (Eds.), Memos to the President on the future of U.S. education policy. Washington, DC: Brookings Institution.

He, Y., Journell, W., \& Faircloth, J. (2018). Preparing teachers for English learners: Integrating academic language and community service projects. The Social Studies, 109(1), 13-26. 
Homza, A., Garrone-Shufran, S., \& Herrmann, B (2014). Linking coursework, fieldwork and professional development: A model for meeting the linguistic needs of English learners. In J. Nagle (Ed.) English learner instruction through collaboration and inquiry in teacher education. Charlotte, NC: Information Age.

Jensen, B., \& Thompson, G. A. (2020). Equity in teaching academic language - An interdisciplinary approach. Theory Into Practice, 59(1), 1-7. DOI:

10.1080/00405841.2019.1665417

Kalinowski, E., Egert, F., Gronostaj, A., \& Vock, M. (2020). Professional development on fostering students' academic language proficiency across the curriculum-A meta-analysis of its impact on teachers' cognition and teaching practices. Teaching and Teacher Education, 88. https://doi.org/10.1016/j.tate.2019.102971

Kieffer, M.J., Lesaux, N.K., \& Snow, C.E. (2007). Promises and pitfalls: Implications of No Child Left Behind for identifying, assessing, and educating English language learners. In G. Sunderman (Ed.), Holding NCLB accountable: Achieving accountability, equity, and school reform. Thousand Oaks, CA: Corwin Press.

Lahey, T. (2017). Collaborating to address the challenge of academic language. Journal of Teacher Education, 68 (3), 239-250.

Lucas, T., Villegas, A.M., \& Freedson-Gonzalez, M. (2008). Linguistically responsive teacher education: Preparing classroom teachers to teach English language learners. Journal of Teacher Education, 59 (4), 361-373.

Macedo, D. (1994). Afterword. In P. Leistyna. Presence of mind. Boulder, CO: Westview Press.

Meier, V., Aminger, W., McLean, M., Carpenter, S.L., Moon, S., Hough, S., \& Bianchini, J.A. (2020). Preservice secondary science teachers' understanding of academic language: Moving beyond "just the vocabulary". Science Education, 104(2), 222-251.

McCorkle, W. D. (2020). The relationship between teachers' grade level and views on immigration and immigrant students. Journal of Social Studies Education Research, 11(1), 21-41.

Morales, J., \& Bardo, N. (2020). Narratives of racial reckoning: Oppression, resistance, and inspiration in English classrooms. Journal of Culture and Values in Education, 3(2), 13856.

National Center for Educational Statistics (2019). National Achievement Level Results. https://www.nationsreportcard.gov/reading/nation/achievement/?grade $=8$

Scarcella, R. (2003). Academic English: A conceptual framework. University of California Linguistic Minority Research Institute.

Schall-Leckrone, L., \& McQuillan, P. (2012). Preparing history teachers to work with English learners through a focus on the academic language of historical analysis. Journal of English for Academic Purposes, 11, 246-266.

Schleppegrell, M.J. (2018). The knowledge base for language teaching: What is the English to be taught as content. Language Teaching Research, 24(1), 17-27. 
Sleeter, C. E. (2008). Preparing white teachers for diverse students. In M. Cochran-Smith, S. Feiman-Nemser, \& D. J. McIntyre (Eds.), Handbook of research on teacher education (3rd ed., pp. 559-582). New York: Routledge.

Snow, C. E., \& Uccelli, P. (2009). The challenge of academic language. In D. R. Olson, \& N. Torrance (Eds.). The Cambridge handbook of literacy (pp. 112-133). Cambridge, England: Cambridge University Press.

Townsend, D. (2015). “Who's using the language? Supporting middle school students with content area academic language. Journal of Adult and Adolescent Literacy 58 (5), 376387.

Turkan, S, deOliveira, L.C., Lee, O., \& Phelps, G. (2014). Proposing a knowledge base for teaching academic content to English language earners: Disciplinary linguistic knowledge. Teachers College Record, 116 (3), 1-30.

Valdés, G., Bunch, G., Snow, C., \& Lee, C., with Matos, L. (2005). Enhancing the development of students' language(s). In L. Darling-Hammond \& J. Bransford (Eds.), Preparing teachers for a changing world: What teachers should learn and be able to do (pp. 126-168). San Francisco, CA: Jossey-Bass.

Willett, J., \& Correa, D. (2014). On making language visible: Reciprocal learning in a professional development alliance. In J. Nagle (Ed.) Creating collaborative learning communities to improve English learner instruction: College faculty, school teachers, and pre-service teachers learning together in the 21st century (pp. 157-71). Charlotte, NC: Information Age.

Zacarian, D. (2013). Mastering academic language: A framework for supporting student achievement. Thousand Oaks, CA: Corwin. 


\section{Appendix - Lesson Planning Worksheet}

Identifying and Teaching the Language of Your Lesson

What are students doing during this lesson in terms of language?

\begin{tabular}{|l|c|}
\hline Listening & Speaking \\
\hline Reading & Writing \\
\hline
\end{tabular}

What are the two most important uses of language for students in this lesson? Why?

1.

2.

Language Functions and Features

1.

Function:

Features of that Function I Could Teach:

\begin{tabular}{|l|l|l|}
\hline Word-Level & Sentence-Level & Discourse-Level \\
\hline
\end{tabular}

2.

Function:

Features of that Function I Could Teach:

\begin{tabular}{|l|l|l|}
\hline Word-Level & Sentence-Level & Discourse-Level \\
\hline
\end{tabular}

Language Objectives

1.

2. 